\title{
Critical Exploration of the Various Forms in George Herbert's The Altar
}

\author{
Dr. Veena R. Ilame
}

Assistant Professor, Department of English, A.G. College, Nagpur, Maharashtra, India

\begin{abstract}
This research paper aims to analyse George Herbert's "The Alter", and its form and they would be discussed concerning its content. Then the article asserts that, while being a visual poem, it is one of the crucial poems composed by the poet in which tropes are exploited with the rest of the forms such as the employment of Metre, Capitalisation and rhymes, strengthening the overall message that poem conveys. George Herbert's The Altar can be seen as just an altar - a quirky form. Nonetheless, that Reading fails to consider how the structure of the poem elevates the meaning of sacrifice. The sacrifice upon the Altar is a sacrifice of the poem (and, in extension, the poet himself). This is a poem that, above all, advocates the total surrender of oneself to a higher deity, no matter how broken that person is.
\end{abstract}

Keywords-Alter, broken, crucial, content, form, Herbert's, poem, tropes, exploited, sacrifice, visual.

\section{INTRODUCTION}

In poetry, there are used words for approximating human circumstance. As such, poetry becomes the art of crafting language, discovering the exact expression to fitting within a line or a stanza. Utilising language as its medium, the form the poem assumes is inalienable from its content. Traditional poetry attains closed forms such as the sonnet and the villanelle. Contemporary poetry, on the other hand, it favours open forms with free verse and prose-poetry.

\section{SORT OF POETICS}

It is this that Visual poetry is an additional form to contend with it, in this sort of poetics, the type of poem proceeds on its content. George Herbert's Easter Wings is in the shape of two wings; his The Altar in the way of a broken altar; John Hollander's Swan and Shadow in the form of a swan and its shadow. Much of the impact of this type of poetry stems from the appearance of the poem on the page (Roberts and Jacobs 741).

It is that this type of poetry takes the discourse on the form to a higher level. In other types of poetry, the style is inherent; closed forms, for example, have a prescribed structure to follow. Visual poetry pushes it by creating its kind of way that would work only in that type of poetry.

Its aesthetic structure flows from its original content.
It is possible to argue that this critical analysis is concerning George Herbert's The Altar. The form would be discussed vis-a-vis its content. The assertion is, while being a visual poem is one of the primary tropes used here, other ways, such as the utilisation of meter, capitalisation and rhymes, strengthen the over-all message that poem seeks to impart.

It is true that, as mentioned, the wedding of form and content in poetry leads to a craft-oriented approach in a reading of any poem. A translated or paraphrased verse might gain new insights from being worked on by an experienced poet-translator. Nonetheless, it would lose a significant deal from changing the language. It has been proposed that the focus on specific elements of craft seemingly can be considered. First, as a visual poem, the shape of the poem is taken into consideration. Particular to this poem involves the usage of capitalised words that lend a higher insight into the poem (Kennedy 696).

This means that Next, the traditional elements of poetry, metrical verse and rhyming patterns add to its effects. Finally, it is sufficient to say that the placement of certain words in the text signifies a specific meaning that is worth reading into as well.

\section{THE THEME OF PRAYER}

It seems that The Altar is a prayer set in poetry. The dramatic situation presented involves the persona of the poem, with nothing else to his name, offering his broken 
self to God. It includes the utter submission and admission of brokenness and suffering that is being highlighted. That brokenness is the only thing that the persona has, and it is that quality that he would be laying on the Altar as an offering. It must further be remembered that the offering is highlighted by the creation of a broken altar, the metaphysical conceit of this poem -- more on this in a while.

It was evident that, on the first form that can be analysed, the shape reflects the entire piece, contextualised by its title. The Altar is a poem about an altar, and it is shaped like an altar. Later on in the poem, it is revealed to be a broken altar. It will be seen, therefore that the creation of the broken Altar echoes the meaning of the verse -- the poem itself is an altar and is an offering.

Second, it necessary to bear in mind that focusing on the physical attributes of the Altar, it would, later on, transcend the boundaries of the temporal plane. The discussion of the Altar is no longer about the broken Altar being created. It is evident from The Altar now is a place of worship and a place of sacrifice. The Altar commences signifying the persona's relationship with God and what significant sacrifices he may be willing to undertake to repair a damaged relationship. It may be that the Altar moves to the self, to the persona's heart and being.

\section{CAPITALISED WORDS}

It seems that the poem has four capitalised words: ALTAR, HEART, SACRIFICE and ALTAR. As

Discussed, in poetry and specifically in visual poetry, the capitalisation gives these words more considerable significance. It is a way for the poet to show that these four words, in particular, should be given more significant meaning than the rest of the poem. For instance, if all the other words in the poem were to be removed, these four would perfectly summarise the insight and message that the poet is trying to impart.

It might, however, be supposed that there are the four words that that capture the significant motifs of the poem. First is the idea that the Altar is a heart, an altar is a sacrifice and, ultimately, the centre is to be sacrificed. It must further be remembered that this Reading through the poem, that is the first message that can be a readout of the Altar. As that is the primary theme of the poem, capitalising them simplifies the task of looking for ulterior ideas that may be embedded within the text.
It is thus clear that the word 'ALTAR' is used twice. Among the four words, it commences and concludes the series of capital letters -- away to see that the Altar is the beginning and the end of the vital message. This means that the Repetition of the word is due to the gravitas of the Altar that in itself bears Repetition. A primary contention of the poem itself is to show how the Altar takes on different forms, either a physical one or a metaphysical one.

In the poem, the four capitalised words also form a diagonal line. On the one hand, it is visually appealing to look at the four capital words in a diagonal line; however, it could also symbolise a crack, or the brokenness within the structure of the Altar, that brokenness that the persona is trying to highlight with the piece. As such, it is within the physical crack in the Altar that important message lies -- another element in showing how it is the quality of brokenness that is being celebrated/offered.

\section{VERBAL STRUCTURE}

It is possible that the placement of words in this poem also signifies something. The term "ALTAR" is seen at the very first line together with the name "Lord". In the structure of the poem, the very first line is the table where the offerings are laid out on. As such, the Altar itself is an offering to the Lord. An alternate reading would be how the Lord is present at every Altar that is created in his name.

The word "ALTAR" is repeated at the very last line. The last line is the foundation of the Altar, visually. Aside from a clean ending, where the end circles back to the beginning, this shows how everything should be built upon an altar and that the foundation of this poem and the persona himself is an altar.

It is this that the word "HEART" is seen near the centre of the poem, visually similar to where the human heart is located within the human body. As such, this displays that the core should be central to what is being done, that the Altar would lose its significance if the human heart. In an enormous scope, the human element of the poem was to be taken out. It also connects the foundation with the upper part of the table -- a means of showing that the heart can bridge what is below with what is above and that the heart is a connector between the temporal and the metaphysical.

\section{ALTER AS A VISUAL POEM}


Some visual poetry tends to forego sound in favour of the optical piece; Herbert's The Altar does not. Music plays a significant factor in this poem; for instance, the usage of the regular meter. It starts with a couplet in iambic pentameter, a couplet in iambic tetrameter, four couplets in iambic dimeter, a couplet in iambic tetrameter and, finally, a couplet in iambic pentameter.

There is a certain regularity with the usage of the meter. The first and most apparent reason for such consistency is for the meter to fit with the visual aspect. The only way one could create an image that looks like the Altar presented is to have the middle part shorter. However, that does not take into account why the opening couplet and the succeeding one have to be of different lengths. Having the opening quatrain in either pentameter or tetrameter would not detract from the structure of the poem

\section{THE METRE EXPLOITED IN THE POEM}

The poem initiates and culminates with a pentameter. Mary Oliver calls the pentameter the closest approximate to one breath that "delivers a message of capability, aptitude, and easy fulfilment" (30). As such, each pentameter line reflects one complete thought, thereby making the poem begin and end with a vast range. Combining the auditory strength of the pentameter with the visual aspect of this poem, one could say that beginning and ending with the pentameter gives this Altar a stronger foundation and a more comprehensive table -in itself, adding to the experience of enjoying the poem.

It seems that the following lines are in tetrameter. Oliver states that shorter lines "leave the reader feeling slightly hurried and, thus, agitated" (31). The tetrameter is best used in fictional works when the feeling of being incomplete propels the reader to read forward. (32) The poem releases with a couple of pentameters, the most potent line structure, and then it shifts to a tetrameter. In effect, after a calming opener, the reader might read the next two lines fast to get to the middle verse more quickly.

It is thus clear that the four couplets in the middle are in dimeter. Oliver likens the dimeter to the dual beat of the heart (32). The usage of the dimeter, aside from making the middle verses shorter to approximate the central part of an altar, is a quick read. Yet it is is that part that contains the heart of what the poem is trying to say, masked under the quirkiness of the dimeter and the structure of the middle section.

Following four couplets of dimeters is a couplet in tetrameter, then a couplet in pentameter. This shows perfect balance -- as above, so below. Dividing the poem into couplets, we end up in a graph as follows: PENTAMETER > TETRAMETER > DIMETER >
DIMETER $>$ DIMETER $>$ DIMETER $>$

\section{TETRAMETER > PENTAMETER}

It is possible to argue that the mirror effect shows symmetry, again another element to be pointed out in this poem. Not only is the poem balanced, but so is the Altar. The Altar has a strong foundation and a long table where one can offer oneself. Inherently, the Altar has a pleasing, symmetrical shape that is violated by a break within it.

The iambic pattern of the poem is another form that could be taken into consideration. As one of the poetry's more famous techniques, the iambic foot closely approximates "sensible speech" (Oliver 15). Using that metrical tool it shows a personal and tender relationship of the persona with God. Furthermore, the rising intonation that the iamb has can double as glorification for God as well.

Aside from the meter, another element of poetry that signifies sound is the rhyme. In this poem, the rhyming scheme is seen per couplet, where the ending sound of each line rhymes with the other line in the couplet. This strengthens the metrical division of the poem, given that a pentameter only rhymes with a fellow pentameter and does not associate with the tetrameters or the dimeters.

The type of rhyme used can be characterised as masculine as the iambic lines end in a stressed sound (Oliver 21). The rhyming occurs within the couplet. Thus, the rhymes are perfect

(40). The verses give the poem a pleasurable form.

It seems that another form to look at in terms of the rhyming scheme is how almost all the rhyming couplets end with an end stop: a colon, a period or a comma. Disregarding the number of stresses per line, this method recalls the usage of the heroic couplets as popularised by poets like Alexander Pope (Aureus 116). Heroic couplets are couplets that rhyme, have an end stop after the couplet and contain within the two lines a single thought that does not continue, semantically, into the next string (Oliver 42).

It is rather strange that the usage of pseudoheroic couplets in this poem shows the movement from couplet to the couplet. As with the divisions in metrical feet, the heroic couplets show that each couplet's message is independent. The end stops at each couplet force the 
reader to slow down and digest the thought forwarded by the couplet.

\section{THE FORM OF THE POEM}

It is this that the form is inconsistent, however, as the couplet, "Wherefore each part//Of my hard heart" does not have an end stop after the word "heart" and the thought of that couplet flows into the next couplet. In effect, that couplet and the one immediately succeeding it have combined to become a quatrain. Factoring in the fact that these four lines are in iambic dimeter lends to how the reader would feel the necessity to speed up reading through that part to get to the ending faster than the beginning eventually. Enabling the sentence has the effect of the narrative forcing the poem forward.

With the discourse on visual poetry and the metrical quality of the poem given, the more significant form to tackle is its genre as a metaphysical poem. It is evident from the kind of a poem is a form that is valid to look into as well. Metaphysical poets are "trying to draw out the traditional lyric of love and devotion by stretching it, under deliberate mental pressure, to encompass new unities from which a sense of strain and violent effort was rarely absent" (Adams 1053).

It can be seen that The metaphysical conceit is to take two different objects and bring them close together to compare them. It is the extension of a physical, commonplace object moving into an elevated metaphysical dimension (Schwartz). In The Altar, the stone altar and the heart are being taken to mean similar purposes.

\section{CONCLUSION}

. To sum up, it might, however, be supposed that this was Rearing a broken stone altar in praise of God is comparable to mending the heart of someone who has lost everything and is offering his whole persona to God. It may be that the only way for a broken altar to be hallowed again is if the heart were a present factor in it. It may be that the tears in the persona are also suggestive of the violent turmoil he may have undergone.

The Altar may be a physical object, and however, when transcended to the metaphysical plane, the Altar becomes a place for offering sacrifices to worship God. The element of sacrifice is prevalent in Christian doctrine as even modern Catholic masses make references to an inevitable sacrifice that everyone partakes in.
Indeed, Digging within the meaning is also the dichotomy between the natural and the human-made. The poem favours the natural creation, forwarding an absolute fatalistic ideal. The natural, as given by God, is inherently present in every man since God made man. The stones used in the creation of the Altar may be dead, and only a man could cut them, preferably with tools. In the poem, the persona has done away with using tools. It echoes the image of God crafting man and being the one who is cutting the rock.

It is declared that another way of looking at the conceit is to argue that true faith does not rely on physical altars. While an actual and literal platform exists in the context of the poem, it is transcended by the more excellent value that sacrifice bestows upon the persona. A grand altar does not mean anything; in the long run, a broken altar is a lot more significant if the person offering himself or herself gives his or her full heart to it.

It must be admitted that tying all the things this paper has brought forward, all of these are a reaffirmation of the necessity of poetic form. The form a poem takes, especially in visual poetry where it is most explicit, achieves a more significant meaning when it is wed with content. Visual poetry uses as its technique the shape of the poem itself; however, that is not all that poetry can offer. Metrical devices such as the stresses, meter and rhyme may seem to be unimportant upon a first glance but are essential devices that prove the meaning of the poem further. Lastly, the historical context of a poem would layer a reading of it in a different light. Religious poetry of the metaphysical kind was a movement during George Herbert's time.

Furthermore, George Herbert's The Altar can be seen as just an altar - a quirky form. But that Reading does not take into account how the structure of the poem elevates the meaning of sacrifice. The sacrifice upon the Altar is a sacrifice of the poem (and, in extension, the poet himself). This is a poem that above all advocates the total surrender of oneself to a higher deity, no matter how broken that person

\section{REFERENCES}

[1] Aureus, Carlos. "Alexander, Pope." Critical Theory As It Is. Quezon City: Carlos Aureus, 2007. 116-117. Print.

[2] Adams, Robert M. "The Seventeenth Century." The Norton Anthology of English Literature. 4th ed. Ed.

[3] M.H. Abrams. New York: W.W. Norton \& Company, 1979. 1049-1058. Print. 
[4] ---. "George Herbert." The Norton Anthology of English Literature. 4th ed. Ed. M.H. Abrams. New York: W.W. Norton \& Company, 1979. 1324-1325. Print.

[5] Herbert, George. "Easter Wings." Literature: An Introduction to Fiction, Poetry, and Drama. 5th ed. Ed. X.J. Kennedy. New York: HarperCollins Publishers, 1991. 694. Print.

[6] ---. "The Altar." The Norton Anthology of English Literature. 4th ed. Ed. M.H. Abrams. New York: W.W. Norton \& Company, 1979. 1329. Print.

[7] Hollander, John. "Swan and Shadow." Literature: An Introduction to Fiction, Poetry, and Drama. 5th ed. Ed. X.J. Kennedy. New York: HarperCollins Publishers, 1991. 695. Print.

[8] Kennedy, X.J. "Poems for the Eye." Literature: An Introduction to Fiction, Poetry, and Drama.

5th ed. Ed. X.J. Kennedy. New York: HarperCollins Publishers, 1991. 694-700. Print.

Oliver, Mary. Rules for the Dance: A Handbook for Writing and Reading Metrical Verse. New York: Houghton Mifflin Company, 1998. Print.

[9] Roberts, Edgar V. and Henry E. Jacobs. "Visual Poetry and Concrete Poetry." Literature: An Introduction to Reading and Writing. 2nd ed. Eds. Edgar V. Roberts and Henry E. Jacobs. New Jersey: Prentice-Hall, 1989. 741. Print.

[10] Schwartz, Deborah B. "John Donne, Ben Jonson and Early 17th-Century Poetry.” California 